\title{
FORCED DEGRADATION STUDY OF STATINS: A REVIEW
}

\author{
RINI YULIANITA ${ }^{1}$, IYAN SOPYAN ${ }^{2}$, MUCHTARIDI MUCHTARIDI ${ }^{*}$
}

${ }^{1}$ Department of Pharmaceutical Analysis and Medicinal Chemistry, Faculty of Pharmacy, Universitas Padjadjaran, Sumedang, West Java, Indonesia 45363, 2Department of Pharmaceutics and Pharmaceutical Technology, Faculty of Pharmacy, Universitas Padjadjaran, Sumedang, West Java, Indonesia 45363

Email: muchtaridi@unpad.ac.id

Received: 12 Aug 2018, Revised and Accepted: 04 Sep 2018

\begin{abstract}
Forced degradation study is the degradation of new drug substances and drug products in more severe conditions than accelerated conditions. Forced degradation study were conducted to demonstrate the specificity of stability-indicating methods, providing insight into degradation pathways and drug degradation products, assisting in the elucidation of degradation product structures, identifying degradation products that could be spontaneously generated during storage and use of drugs and to facilitate improvement in manufacturing process and formulation corresponding with accelerated stability studies. Statins, a class of lipid-lowering medications, are the most widely prescribed drugs and an example of an unstable drug. Statins are susceptible to hydrolysis in the presence of high temperatures and humidity. Therefore, the review discusses various studies of forced degradation studies in six statins drug (atorvastatin, fluvastatin, pitavastatin, pravastatin, rosuvastatin, and simvastatin) to describe the drug's intrinsic stability thus it can assist the selection of formulations and packaging as well as proper storage conditions.
\end{abstract}

Keywords: Forced degradation study, Stress testing, Drugs stability, Statins

(C) 2018 The Authors. Published by Innovare Academic Sciences Pvt Ltd. This is an open-access article under the CC BY license (http://creativecommons.org/licenses/by/4.0/) DOI: http://dx.doi.org/10.22159/ijap.2018v10i6.29086

\section{INTRODUCTION}

The chemical stability of pharmaceutical molecules requires considerable attention because they affect the safety and efficacy of drug products [1]. The Food and Drug Administration (FDA) and International Council for Harmonisation (ICH) Guidelines state the requirements of stability testing data to understand how the quality of a drug substance and drug product changes over time under the influence of various environmental factors. Forced degradation is a process that involves the degradation of drug and drug products in more severe conditions than accelerated conditions and thus results in a degradation product that can be studied to determine molecular stability. In ICH guidelines, stress testing is intended to identify degradation outcomes that further assist in determining the intrinsic molecular stability and establishing degradation pathways, and to validate stability-indicating methods [2,3].

Stress test should be consistent with product decomposition and specific manufacturing, storage, and normal use conditions in each case [4]. The choice of forced degradation conditions should also be based on a good scientific understanding of the mechanisms of decomposition of a product under typical usage conditions, and usually for a 10 to $15 \%$ decomposition rate, which is considered adequate for the validation of chromatographic purity test [5]. The minimum stress factors suggested for forced degradation studies should include acid or base hydrolysis, thermal degradation, photolysis, and oxidation [6].

Statins, inhibitors of 3-hydroxy-3-methylglutarylcoenzyme A (HMG$\mathrm{CoA}$ ) reductase, is used to lower cholesterol by inhibiting the HMGCoA reductase enzyme, which plays a central role in the production of cholesterol in the liver. HMG-CoA reductase catalyzes the conversion of HMG-CoA to mevalonate, a rate-limiting step in cholesterol synthesis. Lovastatin, pravastatin, and simvastatin are inhibitors of HMG-CoA reductase derived from fungi, while atorvastatin, fluvastatin, pravastatin, pitavastatin, and rosuvastatin are completely synthetic compounds [7].

Statins have low bioavailability due to their poor aqueous solubility, low permeability, and high molecular weight of some of their members [8]. The bioavailability of statins varies from $5 \%$ for simvastatin to $60 \%$ or more for pitavastatin [9]. The drugs are divided into four classes in the biopharmaceutical classification system (BCS) based on its solubility. Solubility is a problem in Class
II (i.e. simvastatin and atorvastatin) and IV drugs. There are several methods available to improve solubility, dissolution, and also bioavailability of drugs with poor solubility in water such as physical and chemical modifications, carrier system, micronization, etc. [10]. Formulation simvastatin nanoparticles with single emulsion diffusion method produce $50 \%$ dose reduction without affecting its efficacy [11]. Atorvastatin has low bioavailability (12\%), so it is coated with sodium alginate as a hydrophilic polymer to increase its bioavailability [12]. Other research uses the principle of drug interactions with food/beverage. Oral administration of fresh liquorice drinks with atorvastatin, simvastatin, and lovastatin results in enhancement of drug bioavailability in healthy rats [13].

Statins are susceptible to high temperature and humidity because these drugs have a high risk of hydrolysis. For example, simvastatin is a common cholesterol-lowering drug known to be temperature sensitive. The simvastatin lactone ring is rapidly hydrolyzed into $\beta$ hydroxy acid, simvastatin acid, a process that is affected by the sample temperature $[14,15]$. Therefore, this review discussed the study of forced degradation on six statins drugs (atorvastatin, fluvastatin, pitavastatin, pravastatin, rosuvastatin, and simvastatin). Based on the knowledge of the degradation process and its degradation results, it is expected to assist in the process of formulation, packaging selection, and determination of drug shelf life and storage conditions when the drug is distributed to the public.

\section{Search criteria}

Articles related to forced degradation study, stress testing, drug stability, and statin drugs were used in this review. Authors selected and took the important points from many references that published in 1996-2018.

\section{Force degradation study of statin drugs}

\section{Force degradation study of atorvastatin}

The degradation study of atorvastatin (ATV) was investigated by some researchers with a various method such as liquid chromatography-mass spectroscopy (LC-MS) [16], ultra performance liquid chromatography (UPLC) [17-19], and highperformance liquid chromatography (HPLC) [20-24]. Lakka et al. conducted stress tests on ATV with HPLC method. The stress tests were performed on the sample include reflux with $0.1 \mathrm{~N} \mathrm{HCl}$ at $60^{\circ} \mathrm{C} / 30 \mathrm{~min}$, reflux with $0.1 \mathrm{~N} \mathrm{NaOH}$ at $60{ }^{\circ} \mathrm{C} / 30 \mathrm{~min}$, reflux with $1 \% \mathrm{H}_{2} \mathrm{O}_{2}$ at 60 
${ }^{\circ} \mathrm{C} / 30 \mathrm{~min}$, exposed to dry heat at $105^{\circ} \mathrm{C} / 6 \mathrm{~h}$ in the oven, reflux at $60{ }^{\circ} \mathrm{C} / 30 \mathrm{~min}$ in water, exposed to visible light 1.2 million lux-hours, UV light 200 Watt-hours $/ \mathrm{m}^{2}$, and stored in humidity chamber at 25 ${ }^{\circ} \mathrm{C} / 90 \% \mathrm{RH}$ for $7 \mathrm{~d}$. Degradation was not observed in stress tests with visible light, UV, moisture, and hydrolysis of water. Acid hydrolysis, alkaline hydrolysis, and oxidative conditions showed no significant degradation. However, thermal stress indicated significant degradation [25]. Aiyalu et al. studied stress tests on ATV with high-performance thin layer chromatography (HPTLC) method. Stress tests were conducted in ATV sample such as neutral hydrolysis $\left(80^{\circ} \mathrm{C}, 1 \mathrm{~h}\right)$, acid $\left(0.1 \mathrm{M} \mathrm{HCl}, 8 \mathrm{~h}, 80^{\circ} \mathrm{C}\right)$, acid $(1 \mathrm{M} \mathrm{HCl}, 8 \mathrm{~h}$, elevated temperature $\left(80^{\circ} \mathrm{C}\right)$, base $\left(0,1 \mathrm{M} \mathrm{NaOH}, 8 \mathrm{~h}, 80^{\circ} \mathrm{C}\right)$, base $(1$ $\mathrm{M} \mathrm{NaOH}, 8 \mathrm{~h}$, elevated temperature $\left(80{ }^{\circ} \mathrm{C}\right)$, oxidative $\left(3 \% \mathrm{H}_{2} \mathrm{O}_{2}, 6\right.$ $h$, room temperature), oxidative $\left(30 \% \mathrm{H}_{2} \mathrm{O}_{2}, 24 \mathrm{~h}\right.$, room temperature), dry heat $\left(30 \mathrm{~d}, 50^{\circ} \mathrm{C}\right)$, and photolysis (UV, $\left.2 \mathrm{~d}\right)$. ATV had significant degradation in acid hydrolysis $(86.14 \%$ degraded at $80{ }^{\circ} \mathrm{C}, 89.63 \%$ degraded at elevated temperature $\left(80{ }^{\circ} \mathrm{C}\right)$ ) and oxidative stress $\left(52.23 \%\right.$ degraded at $3 \% \mathrm{H}_{2} \mathrm{O}_{2}, 45.32 \%$ degraded at $30 \% \mathrm{H}_{2} \mathrm{O}_{2}$ ) [26].

Goel et al. conducted a stress test with UPLC method. ATV was subjected to acid $\left(1 \mathrm{~N} \mathrm{HCl}, 25^{\circ} \mathrm{C}, 5 \mathrm{~min}\right)$, base $\left(0.01 \mathrm{~N} \mathrm{NaOH}, 25^{\circ} \mathrm{C}, 5\right.$ min), neutral (water, $80{ }^{\circ} \mathrm{C}, 4 \mathrm{~h}$ ), strong oxidation $\left(30 \% \mathrm{H}_{2} \mathrm{O}_{2}, 80^{\circ} \mathrm{C}\right.$, $1 \mathrm{~h}$ ), thermal $\left(80^{\circ} \mathrm{C}, 1 \mathrm{~d}\right)$, and photolysis stress conditions (UV at $254 \mathrm{~nm}, 1 \mathrm{~d}$ ). ATV was found to be sensitive to acid hydrolysis (80.9 $\%$ assay). The degradation study with $1 \mathrm{~N} \mathrm{HCl}$ resulted in the lactone form of ATV as the primary degradation product in retention time (Rt) $1.941 \mathrm{~min}$. ATV was stable in alkaline hydrolysis, in water at room temperature, in $30 \% \mathrm{H}_{2} \mathrm{O}_{2}$ at room temperature, in dry heat at $80{ }^{\circ} \mathrm{C}$ and UV light for one day. However, ATV was found unstable after water hydrolysis at $80{ }^{\circ} \mathrm{C}$ and produced a major degradation product in Rt $1.932 \mathrm{~min}$. After heating in $\mathrm{H}_{2} \mathrm{O}_{2}$ at $80{ }^{\circ} \mathrm{C}$, ATV produced two minor degradation products in Rt 2.292 and 2.661 min [27]. S. Naidu et al. performed the stress test on ATV with HPLC method. The samples were subjected to acid hydrolysis, alkaline hydrolysis, oxidation, and light stress. ATV was relatively stable at photolysis stress (UV, $24 \mathrm{~h}$ ), slightly degraded on alkaline hydrolysis $(0.1 \mathrm{M} \mathrm{NaOH})$, oxidation stress $\left(3 \% \mathrm{H}_{2} \mathrm{O}_{2}\right)$, and acid hydrolysis $(0.1$ $\mathrm{M} \mathrm{HCl})$ [28].

\section{Force degradation study of fluvastatin}

Akabari et al. conducted a stress test on fluvastatin (FVS) with HPLC method. Samples for degradation studies underwent basic hydrolysis $\left(0.1 \mathrm{M} \mathrm{NaOH}, 70{ }^{\circ} \mathrm{C}, 120 \mathrm{~min}\right)$, acid $\left(0.1 \mathrm{M} \mathrm{HCl}, 70{ }^{\circ} \mathrm{C}, 120\right.$ min and $\left.1 \mathrm{M} \mathrm{HCl}, 70{ }^{\circ} \mathrm{C}, 30 \mathrm{~min}\right)$, oxidative $\left(3 \% \mathrm{H}_{2} \mathrm{O}_{2}, 70{ }^{\circ} \mathrm{C}, 120\right.$ min), thermal $\left(80^{\circ} \mathrm{C}, 24 \mathrm{~h}\right.$ ), and photolysis (direct sunlight, $24 \mathrm{~h}$ ). FVS was found susceptible to acid, alkaline hydrolysis, and oxidative stress. FVS was unstable and degraded rapidly (about $45 \%$ hour, $10.1 \%$ assay) when exposed to acidic conditions in $0.1 \mathrm{M} \mathrm{HCl}$. Base and oxidative stress resulted in $61.2 \%$ and $43 \%$ drug decomposition, a decrease in original peak area and no additional peaks were observed in the chromatogram. FVS underwent thermal and photolysis degradation slightly $(2.65 \%$ and $6.47 \%)$ and no additional peaks were observed in chromatogram [29]. Gomes et al. conducted a degradation study on FVS by HPLC method. The sample had neutral hydrolysis (water, $80{ }^{\circ} \mathrm{C}, 2 \mathrm{~h}$ ), chemical oxidation ( $3 \%$ $\left.\mathrm{H}_{2} \mathrm{O}_{2}, 80{ }^{\circ} \mathrm{C}, 2 \mathrm{~h}\right)$, acid hydrolysis $\left(1.0 \mathrm{~mol} / \mathrm{l} \mathrm{HCl}, 8{ }^{\circ} \mathrm{C}, 2 \mathrm{~h}\right)$, and alkaline hydrolysis $\left(1.0 \mathrm{~mol} / \mathrm{l} \mathrm{NaOH}, 80^{\circ} \mathrm{C}, 2 \mathrm{~h}\right)$. FVS was stable in neutral hydrolysis. However, after chemical oxidation test, there had been modified in the chromatogram. After acid and base hydrolysis, the chromatogram showed many additional peaks of degradation products [30].

\section{Force degradation study of pitavastatin}

Aglawe et al. studied a stress test on pitavastatin (PTV) with UVVisible spectrophotometry method. The PTV stress test was performed in acid hydrolysis $\left(0.1 \mathrm{~N} \mathrm{HCl}, 5 \mathrm{~h}, 60^{\circ} \mathrm{C}\right)$, basic hydrolysis $\left(0.1 \mathrm{~N} \mathrm{NaOH}, 5 \mathrm{~h}, 60{ }^{\circ} \mathrm{C}\right.$ ), neutral hydrolysis (water, $5 \mathrm{~h}, 60^{\circ} \mathrm{C}$ ), oxidative $\left(3 \% \mathrm{H}_{2} \mathrm{O}_{2}\right.$, dark conditions, $\left.6 \mathrm{~h}\right)$, heat $\left(60{ }^{\circ} \mathrm{C}, 12 \mathrm{~h}\right)$, and photolysis (direct sunlight, $12 \mathrm{~h}$ and UV light, $48 \mathrm{~h}$ ). The degradation studies showed that PTV was degraded significantly under acidic, alkaline, neutral, photolysis, thermal, oxidation, and light stress conditions (23.35 \%-82.31 \% drug degraded) [31]. In another study, degradation study using HPTLC method was conducted. Samples were exposed to acid $\left(0.1 \mathrm{M} \mathrm{HCl}, 4 \mathrm{~h}, 75^{\circ} \mathrm{C}\right)$, base hydrolysis $(0.1 \mathrm{M}$ $\left.\mathrm{NaOH}, 2 \mathrm{~h}, 75^{\circ} \mathrm{C}\right)$, oxidation $\left(3 \% \mathrm{H}_{2} \mathrm{O}_{2}, 2 \mathrm{~h}, 75^{\circ} \mathrm{C}\right)$, heat $\left(75^{\circ} \mathrm{C}, 24\right.$ h), and photodegradation study (254 nm UV radiation, $24 \mathrm{~h}$ ). PTV was sensitive to acid hydrolysis (degraded $\pm 7.5 \% / h$ ) and an additional band (retention factor (Rf) 0.53) appeared in the chromatogram. PTV had stability under alkaline conditions and showed an additional band at Rf 0.55. PTV was stable in thermal, and UV ( $>90 \%$ recovery). Chromatogram showed two additional bands (Rf 0.28 and 0.58 ) in oxidative stress and three additional bands (Rf $0.53,0.58$, and 0.61 ) in thermal degradation. Samples exposed to UV light showed an additional band at Rf 0.55 [32].

Damle et al. investigated PTV degradation results by HPTLC method. The drug was tested with stress on acidic $(0.1 \mathrm{~N} \mathrm{HCl}, 30 \mathrm{~min}$, room temperature), base $(0.1 \mathrm{~N} \mathrm{NaOH}, 2 \mathrm{~h}$, room temperature), neutral (water, $30 \mathrm{~min}$, room temperature), oxidation $\left(3 \% \mathrm{H}_{2} \mathrm{O}_{2}, 2 \mathrm{~h}\right.$, room temperature), thermal degradation $\left(80^{\circ} \mathrm{C}, 6 \mathrm{~h}\right.$ ), and photolysis (UV light, 200 Watt-hours $/ \mathrm{m}^{2}$ and fluorescence light, 1.2 million luxhours) conditions. PTV had significant degradation in photolysis conditions, thermal and alkaline hydrolysis. PTV underwent degradation slightly in acid hydrolysis, and the chromatogram showed one additional band at Rf 0.70 . Mild degradation occurred in neutral hydrolysis and oxidative stress [33]. Panchal et al. performed a stress test with the HPLC method. The drug was tested with acid $\left(0.01 \mathrm{M} \mathrm{HCl}, 1 \mathrm{~h}, 60^{\circ} \mathrm{C}\right)$, base $\left(0.01 \mathrm{M} \mathrm{NaOH}, 10 \mathrm{~min}, 60^{\circ} \mathrm{C}\right)$, neutral (water, $1 \mathrm{~h}, 60^{\circ} \mathrm{C}$ ) hydrolysis, oxidation $\left(0.3 \% \mathrm{H}_{2} \mathrm{O}_{2}, 1 \mathrm{~h}, 60\right.$ ${ }^{\circ} \mathrm{C}$ ), heat $\left(60^{\circ} \mathrm{C}, 4 \mathrm{~h}\right)$, and photodegradation studies (visible light, 12 $\mathrm{h}$ and UV light, $4 \mathrm{~h}$ ). PTV was heavily degraded (47 \%) in basic media and moderately degraded ( $27 \%$ ) in acidic media, yielding major and minor degradation products at Rt 2.60 and 3.90 min. Under neutral conditions, $10 \%$ of the drug was degraded, with no major degradation products and two minor degradation products at Rt of 2.60 and $3.90 \mathrm{~min}$. However, PTV was relatively stable in neutral conditions. PTV was $70 \%$ degraded in oxidative stress, with no major degradation products and minor degradation products at Rt within 1.5-3.0 min. In thermal stress conditions, PTV was quite stable (11\% degradation) and minor degradation products were found at Rt range 1.5-3.0 min. After PTV was exposed to visible and UV light, the drug was degraded with $10 \%$ and $9 \%$ degradation, respectively [34]. A stress test by HPLC method was studied by Sujatha et al. The degradation studies were performed in acid hydrolysis $\left(2 \mathrm{M} \mathrm{HCl}, 30 \mathrm{~min}, 60^{\circ} \mathrm{C}\right)$, alkaline hydrolysis $(2 \mathrm{M} \mathrm{NaOH}$, $30 \mathrm{~min}, 60^{\circ} \mathrm{C}$ ), neutral hydrolysis (water, $\left.6 \mathrm{~h}, 60^{\circ} \mathrm{C}\right)$, oxidative $(20$ $\% \mathrm{H}_{2} \mathrm{O}_{2}, 30 \mathrm{~min}, 60^{\circ} \mathrm{C}$ ), thermal $\left(105^{\circ} \mathrm{C}, 6 \mathrm{~h}\right.$ ), and photolysis (UV room, $7 \mathrm{~d}$ ). The degradation study obtained additional peaks in the chromatogram compared to standard PTV (Rt $3.823 \mathrm{~min}$ ), acid hydrolysis ( 2 additional peaks at 2.889 and $5.143 \mathrm{~min}$ ), alkaline hydrolysis ( 2 additional peaks at 2.733 and $13.376 \mathrm{~min}$ ), neutral hydrolysis (an additional peak at $13.025 \mathrm{~min}$ ), oxidative (2 additional peaks at 2.733 and $13.376 \mathrm{~min}$ ), thermal ( 2 additional peaks at 5.366 and $6.071 \mathrm{~min}$ ) and photolysis ( 2 additional peaks at 5.290 and $5.988 \mathrm{~min}$ ) [35].

\section{Force degradation study of pravastatin}

Onal and Sagirli performed degradation study on pravastatin (PRV) with HPLC method. The stress conditions are carried out in acid hydrolysis $\left(1 \mathrm{~N} \mathrm{HCl}, 1 \mathrm{~h}, 80^{\circ} \mathrm{C}\right)$, alkaline hydrolysis $(1 \mathrm{~N} \mathrm{NaOH}, 1 \mathrm{~h}$, $80{ }^{\circ} \mathrm{C}$ ), neutral hydrolysis (water, $1 \mathrm{~h}, 80^{\circ} \mathrm{C}$ ), oxidative $\left(30 \% \mathrm{H}_{2} \mathrm{O}_{2}\right.$, $\left.1 \mathrm{~h}, 80^{\circ} \mathrm{C}\right)$, thermal $\left(105^{\circ} \mathrm{C}, 5 \mathrm{~h}\right)$, and photolysis (366 nm UV light, $10 \mathrm{~h}$ ). Neutral hydrolysis caused $10 \%$ reduction in original drug peak and two additional peaks at Rt 1.53 and 3.20 min. In base hydrolysis, chromatogram showed $\pm 90 \%$ reduction of the original drug peak and two additional peaks at Rt 0.99 and 1.82 min. Under oxidative stress, the peak of the chromatogram was reduced $\pm 30 \%$ of the original drug peak and a new peak appeared at Rt $1.54 \mathrm{~min}$. In acid hydrolysis, the peak corresponding to the parent drug disappeared and two new peaks appeared at Rt 1.53 and $1.71 \mathrm{~min}$. The chromatogram did not undergo any changes in thermal stress. Drugs degraded $50 \%$ and new small peak appeared at Rt $1.60 \mathrm{~min}$ on UV exposure [36].

Athota et al. tested the degradation of PRV by HPLC method. Stress studies were performed in acid $(0.1 \mathrm{~N} \mathrm{HCl}, 30 \mathrm{~min})$, base $(0.1 \mathrm{~N} \mathrm{NaOH}$, $30 \mathrm{~min})$, oxidative $\left(30 \% \mathrm{H}_{2} \mathrm{O}_{2}, 30 \mathrm{~min}\right)$, thermal $\left(105^{\circ} \mathrm{C}, 30 \mathrm{~min}\right)$, and photolysis (sunlight, $24 \mathrm{~h}$ ). PRV was more degraded in acid hydrolysis 
and less degraded in oxidative stress. The test results showed $4.35 \%$ of the drug was degraded under acidic conditions, $4.21 \%$ in basic, 2.20 $\%$ in oxidative stress, $3.27 \%$ in thermal stress and $2.88 \%$ in photolysis [37]. Ahmad et al. conducted a stress test by HPTLC method. Samples were tested with acid, base, oxidative, thermal, UV, and photolysis stress. Acid degradation was slower than the basic condition. The degradation products were observed at Rf 0.28 and 0.53 when the drug was heated with $\mathrm{HCl} 1 \mathrm{M}$ at $80^{\circ} \mathrm{C}$ for $8 \mathrm{~h}$. The drug underwent very fast basic degradation in $1 \mathrm{M} \mathrm{NaOH}$ at $80^{\circ} \mathrm{C}$, about 80 $\%$ of the drug was degraded within 5 min and degradation products were observed at $\operatorname{Rf} 0.24,0.40$, and 0.52 . Under oxidative stress ( $30 \%$ $\mathrm{H}_{2} \mathrm{O}_{2}$, room temperature, $24 \mathrm{~h}$ ), the degradation products were observed at Rf $0.24,0.40$, and 0.52 . In UV radiation ( $254 \mathrm{~nm}$ ), PRV was degraded slowly, yielding four additional peaks at Rf 0.29, 0.37, 0.55, and 0.78 . The drug was almost stable in heat and sunlight, with additional peaks at Rf 0.53 and Rf 0.29 [38].

\section{Force degradation study of rosuvastatin}

The stress test on rosuvastatin (RSV) with a various method such as HPLC [39], UPLC [40], TLC [41], and UV spectrophotometry [42] was conducted in the previous study. Trivedi et al. conducted stress test with UPLC method in acid hydrolysis $\left(0.1 \mathrm{~N} \mathrm{HCl}, 80^{\circ} \mathrm{C}, 2 \mathrm{~h}\right)$, alkaline hydrolysis $\left(0.5 \mathrm{~N} \mathrm{NaOH}, 80^{\circ} \mathrm{C}, 6 \mathrm{~h}\right)$, oxidative $\left(3 \% \mathrm{H}_{2} \mathrm{O}_{2}, 80^{\circ} \mathrm{C}, 6 \mathrm{~h}\right)$, thermal $\left(100{ }^{\circ} \mathrm{C}, 8 \mathrm{~h}\right)$, and photolysis (UV light). No significant degradation was observed in oxidative stress, thermal stress, and alkaline hydrolysis. In contrast, significant degradation was observed in acid hydrolysis and UV light. Anti-rosuvastatin isomer and unknown impurities were formed [43]. Shah et al. conducted degradation study under stress conditions determined by ICH Guidelines with the HPLC method. Stress studies were performed in acid $(0.1 \mathrm{~N} \mathrm{HCl})$, base $(2 \mathrm{~N} \mathrm{NaOH})$, oxidative $\left(30 \% \mathrm{H}_{2} \mathrm{O}_{2}\right)$, thermal (50 ${ }^{\circ} \mathrm{C}$ for $21 \mathrm{~d}$ ), and photolysis stress (fluorescence $\sim 8,500$ lux and UV light $\sim 0.5 \mathrm{~W} / \mathrm{m}^{2}$ ). Drugs degraded mainly in hydrolysis and photolysis conditions. Five degradation products were formed in acid hydrolysis and acidic photolysis conditions. One degradation product was formed in neutral and oxidative conditions. Two degradation products were produced at all photolysis conditions, including solid photolysis. The drug was stable against alkaline hydrolysis and thermal stress. The LCMS analysis showed that five degradation products had the same molecular mass as in the drug, while the other six had a molecular mass of 18 Da less than the drug [44].

Ashfaq et al. studied RSV degradation with HPLC method. Stress conditions were performed under acid hydrolysis $\left(5 \mathrm{M} \mathrm{HCl}, 60^{\circ} \mathrm{C}, 4\right.$ h), alkaline hydrolysis $\left(5 \mathrm{M} \mathrm{NaOH}, 60^{\circ} \mathrm{C}, 4 \mathrm{~h}\right)$, oxidative $\left(6 \% \mathrm{H}_{2} \mathrm{O}_{2}\right.$, room temperature, $24 \mathrm{~h})$, thermal $\left(60^{\circ} \mathrm{C}, 4 \mathrm{~h}\right)$, and photolysis $(366$ $\mathrm{nm}$ UV light, $10 \mathrm{~h}$ ). RSV was highly degraded in acidic condition (40 $\%)$. At oxidative and basic stress, RSV had mild degradation with 6 $\%$ and $5 \%$ degradation, respectively. Thermal stress had no effect on drug degradability [45]. However, other study stated that the drugs contained RSV and ezetimibe are highly sensitive towards alkaline conditions in comparison to other stress conditions [46]. Bellal et al. performed a stress test with the TLC method. The stress conditions were oxidative $\left(10 \% \mathrm{H}_{2} \mathrm{O}_{2}, 100{ }^{\circ} \mathrm{C}, 10 \mathrm{~min}\right)$, photolysis (UV light $254 \mathrm{~nm}, 30-120 \mathrm{~min})$, thermal $\left(100^{\circ} \mathrm{C}, 10 \mathrm{~min}\right)$, acid $(0.1 \mathrm{M}$ $\left.\mathrm{HCl}, 100^{\circ} \mathrm{C}, 5 \mathrm{~min}\right)$, and base $\left(0.1 \mathrm{M} \mathrm{NaOH}, 100^{\circ} \mathrm{C}, 5 \mathrm{~min}\right)$ hydrolysis. Under acid hydrolysis conditions, four major degradation products were detected with $\mathrm{Rf}$ values of $0.16,0.27,0.74$, and 0.77 . In alkaline hydrolysis, one major degradation product was detected at Rf 0.73 . At thermal stress, two major degradation products were formed at Rf 0.74 and 0.77 . The drug was more susceptible to oxidative stress than other conditions because five major degradation products are formed at Rf $0.15,0.25,0.30,0.71$, and 0.77 . At photolysis stress, two major degradation products were detected at Rf 0.70 , and 0.78 [47].

\section{Force degradation study of simvastatin}

The degradation in simvastatin (SIM) was conducted in previous study with HPLC method [48-51], UPLC (52) and UV derivative spectrophotometry [53]. Samples were tested with neutral hydrolysis (water, $100^{\circ} \mathrm{C}, 4 \mathrm{~h}$ ), acid $\left(1 \mathrm{~N} \mathrm{HCl}, 100^{\circ} \mathrm{C}, 4 \mathrm{~h}\right)$ and base $\left(1 \mathrm{~N} \mathrm{NaOH}, 100{ }^{\circ} \mathrm{C}, 4 \mathrm{~h}\right)$, oxidation $\left(30 \% \mathrm{H}_{2} \mathrm{O}_{2}, 100^{\circ} \mathrm{C}, 4 \mathrm{~h}\right)$, dry heat $\left(105^{\circ} \mathrm{C}, 4 \mathrm{~h}\right)$, and UV exposure $(254 \mathrm{~nm}, 4 \mathrm{~h})$. By HPLC method SIM was still observed in the presence of their degradation products after acid hydrolysis. However, SIM was more sensitive to alkaline hydrolysis and underwent complete degradation. The peak (Rt 4.2 min) after alkaline and neutral hydrolysis could be identified as hydroxyl acid form of SIM. After oxidation, the degradation product peak was detected at Rt $2.55 \mathrm{~min}$ and did not interfere with SIM retention time (Rt $6.5 \mathrm{~min}$ ). At thermal stress and UV exposure, SIM did not show any degradation [54].

Ghodke undertook degradation study with HPLC method. The sample under various conditions such as neutral (water, $70^{\circ} \mathrm{C}, 1 \mathrm{~h}$ ), acid $\left(3 \mathrm{M} \mathrm{HCl}, 70{ }^{\circ} \mathrm{C}, 6 \mathrm{~h}\right)$, basic $\left(1 \mathrm{M} \mathrm{NaOH}, 80^{\circ} \mathrm{C}, 3 \mathrm{~h}\right)$ hydrolysis, oxidation $\left(30 \% \mathrm{H}_{2} \mathrm{O}_{2}, 8 \mathrm{~h}, 25^{\circ} \mathrm{C}\right)$, thermal $\left(80^{\circ} \mathrm{C}\right)$, and photolysis (exposure to short and long UV radiation, $48 \mathrm{~h}$ ) conditions. Chromatograms of acid and base degradation showed an additional peak at Rt 6.2 min and Rt 6.3 min. Peaks of degradation product were not found in neutral hydrolysis, oxidative, thermal and photolysis stress conditions [55]. Chavhan and Ghante conducted the stress test on SIM with UV spectrophotometry method. The stability studies were carried out under acidic $\left(0.1 \mathrm{~N} \mathrm{HCl}, 60^{\circ} \mathrm{C}, 3 \mathrm{~h}\right)$, base $\left(0.1\right.$ to $\left.5 \mathrm{~N} \mathrm{NaOH}, 60^{\circ} \mathrm{C}, 36 \mathrm{~h}\right)$, neutral (water, $60{ }^{\circ} \mathrm{C}, 3 \mathrm{~h}$ ), oxidative $\left(3 \% \mathrm{H}_{2} \mathrm{O}_{2}, 60{ }^{\circ} \mathrm{C}, 14 \mathrm{~h}\right)$, thermal $\left(80^{\circ} \mathrm{C}, 4 \mathrm{~h}\right)$, and photolysis (sunlight, $4 \mathrm{~h}$ ) conditions. SIM was found to be stable in basic ( $5 \mathrm{~N} \mathrm{NaOH}$ up to $36 \mathrm{~h}$ ) and photolysis conditions (in sunlight up to $8 \mathrm{~d}$ ) when compared to other conditions. SIM was found to be unstable in acid, neutral, oxidative, and thermal conditions [56].

Sawant and Ghante reported SIM stability based on a study of forced degradation with HPLC method. The stability studies of the SIM were performed under acidic $\left(0.1 \mathrm{~N} \mathrm{HCl}, 80{ }^{\circ} \mathrm{C}, 3 \mathrm{~h}\right)$, base $(0.1 \mathrm{~N}$ $\mathrm{NaOH}, 80^{\circ} \mathrm{C}, 2 \mathrm{~h}$ ), neutral (water, $80{ }^{\circ} \mathrm{C}, 3 \mathrm{~h}$ ), oxidative $\left(3 \% \mathrm{H}_{2} \mathrm{O}_{2}\right.$, $60{ }^{\circ} \mathrm{C}, 14 \mathrm{~h}$ ), thermal $\left(50^{\circ} \mathrm{C}, 21 \mathrm{~d}\right)$, and photolysis (fluorescence light 8500 lux-hours and UV light 0.5 Watt-hours $/ \mathrm{m}^{2}$ at $40{ }^{\circ} \mathrm{C} / 75 \% \mathrm{RH}$, $13 \mathrm{~d})$ conditions. The drug was degraded under all stress conditions except photolysis. No significant degradation $(<0.45 \%)$ occurred in photolysis conditions. The degradation product of SIM was identified as 2 dihydroxy derivatives of SIM [57]. Malenovic et al. analyzed the degradation product using microemulsion liquid chromatography. The degradation was expected that simvastatin as lacton would be very susceptible to hydrolysis [58]. Nalaiya et al. tested the forced degradation of SIM with HPLC method. Active substances and finished products are tested with acid, alkaline, oxidation, heat, and photolysis stress conditions. Within $24 \mathrm{~h}$, SIM was totally degraded under acidic conditions $\left(1 \mathrm{~N} \mathrm{HCl}, 50{ }^{\circ} \mathrm{C}\right)$ and 90 $\%$ degraded in its finished products. SIM was also degraded under oxidative stress $\left(0.3 \% \mathrm{H}_{2} \mathrm{O}_{2}, 50{ }^{\circ} \mathrm{C}\right.$ ) and neutral hydrolysis (water, $90^{\circ} \mathrm{C}$ ). However, SIM was relatively stable under alkaline hydrolysis $\left(1 \mathrm{~N} \mathrm{NaOH}, 50^{\circ} \mathrm{C}\right.$ ) and photolysis (UV light, $24 \mathrm{~h}$ ) [59].

\section{CONCLUSION}

Forced degradation studies provide knowledge of possible degradation pathways and degradation of active ingredients and help explain degradation structures. The degradation product resulting from forced degradation studies is a potential degradation product likely to be formed under suitable storage conditions. From the results of forced degradation studies on Statin drugs, all drugs have a tendency to degrade in all stressful conditions i.e. acid, base, neutral hydrolysis, oxidation, thermal and photolysis of a certain degree depending on the concentration and duration of stress exposure. This demonstrates the instability of statin drugs, so it requires special treatment starting from active ingredient formulation, packaging, distribution and storage of the final product.

\section{AUTHORS CONTRIBUTIONS}

All the author have contributed equally

\section{CONFLICTS OF INTERESTS}

All authors have none to declare

\section{REFERENCES}

1. Singh S, Junwal M, Modhe G, Kurmi M, Parashar N, Sidduri P. Forced degradation studies to assess the stability of drugs and products. Trends Anal Chem 2013;49:1-41.

2. ICH Expert Working Group. ICH guideline Q1A (R2): stability testing of new drug substances and products. Int Conf Harmon; 2003. p. 24. 
3. Blessy M, Patel RD, Prajapati PN, Agrawal YK. Development of forced degradation and stability indicating studies of drugs-a review. J Pharm Anal 2014;4:159-65.

4. Jenke DR. Chromatographic method validation: a review of current practices and procedures. II. Guidelines for primary validation parameters. J Liq Chromatogr 1996;19:737-57.

5. Ferenczi Fodor K, Vegh Z, Renger B. Impurity profiling of pharmaceuticals by thin-layer chromatography. J Chromatogr A 2011; 1218:2722-31.

6. Bakshi M, Singh S. Development of validated stabilityindicating assay methods-critical review. J Pharm Biomed Anal 2002;28:1011-40.

7. Davidson MH. Rosuvastatin: a highly efficacious statin for the treatment of dyslipidemia. Expert Opin Investig Drugs 2002;11:125-41.

8. Petyaev IM. Improvement of hepatic bioavailability as a new step for the future of statin. Arch Med Sci 2015;11:406-10.

9. Schachter M. Chemical, pharmacokinetic and pharmacodynamic properties of statins: an update. Fundam Clin Pharmacol 2004;19:117-25.

10. Sanjaymitra PVSS, Ganesh GNK. Dissolution and solubility enhancement strategies: current and novel prospectives. J Crit Rev 2018;5:1-10.

11. Gupta D, Mandowara V, Patel S, Shelat P. Improvement of efficacy and safety profile of simvastatin in comparison to the reference product (Zocor tablets) using nanoparticulate formulation approach. Int J Curr Pharm Res 2016;8:39-47.

12. Reddy KVR, Nagabhushanam MV. The role of the needle in the formulation of $\mathrm{pH}$-sensitive swellable microbeads prepared with hydrophilic polymers for atorvastatin and their characterization studies. Int J Appl Pharm 2017;9:20-30.

13. Dayyih WAABU, Mallah EM, Al-Ani IH, Arafat TA. Liquorice beverage effect on the pharmacokinetic parameters of atorvastatin, simvastatin, and lovastatin by liquid chromatography-mass spectroscopy/mass spectroscopy. Asian J Pharm Clin Res 2016;9:174-9.

14. Alvarez Lueje A, Valenzuela C, Squella JA, Nunez-Vergara LJ. Stability study of simvastatin under hydrolytic conditions assessed by liquid chromatography. J AOAC Int 2005;88:1631-6.

15. Jemal M, Zheng O, Powell ML. Direct-injection LC-MS-MS method for high-throughput simultaneous quantitation of simvastatin and simvastatin acid in human plasma. J Pharm Biomed Anal 2000;23:323-40.

16. Shah RP, Kumar V, Singh S. Liquid chromatography/mass spectrometric studies on atorvastatin and its stress degradation products. Rapid Commun Mass Spectrom 2008;22:613-22.

17. Kadav AA, Vora DN. Stability-indicating UPLC method for simultaneous determination of atorvastatin, fenofibrate, and their degradation products in tablets. J Pharm Biomed Anal 2008;48:120-6.

18. Vora DN, Kadav AA. Validated ultra HPLC method for the simultaneous determination of atorvastatin, aspirin, and their degradation products in capsules. J Liq Chromatogr Relat Technol 2008;31:2821-37.

19. Kumar KK, Rao CK. A validated stability indicating RP-UPLC method for atorvastatin calcium. Am J Anal Chem 2012;3:392-9.

20. Vukkum P, Abu JMOB, Uralikrishna RM. Stress degradation behavior of atorvastatin calcium and development of a suitable stability-indicating LC method for the determination of atorvastatin, its related impurities, and its degradation products. Sci Pharm 2013;81:93-114.

21. Gite S, Patravale V. Validation of RP-HPLC method and stress degradation for the combination of metformin $\mathrm{HCl}$, atorvastatin calcium, and glimepiride: application to nanoparticles. J Chromatogr Sci 2015;53:1654-62.

22. Singh S, Dahiya R. Stability-indicating RP-HPLC method for estimation of atorvastatin calcium in the solid dosage form. Bull Pharm Res 2014;4:9-13.

23. Sathiyasundar KVR. New stability indicating assay method by liquid chromatographic separation of aspirin, atorvastatin, and clopidogrel in the pharmaceutical dosage form. Indo Am J Pharm Res 2014;4:5919-27.

24. Oliveira MA, Yoshida MI, Belinelo VJ, Valotto RS. Degradation kinetics of atorvastatin under stress conditions and chemical analysis by HPLC. 2013;18:1447-56.
25. Lakka NS, Goswami N, Balakrisna VSP. Development and validation of a stability-indicating RP-HPLC for the simultaneous determination of atorvastatin calcium and simvastatin in pharmaceutical solid dosage forms. Int J Res Pharm Sci 2011;2:608-15.

26. Aiyalu R, Mani K. HPTLC method development, validation, and stress degradation studies for atorvastatin and ezetimibe in the multicomponent tablet dosage form. Med Chem Res 2012;21:1297-301.

27. Goel A, Baboota S, Sahni JK. Development and validation of stability-indicating assay method by UPLC for a fixed dose combination of atorvastatin and ezetimibe. J Chromatogr Sci 2013;51:222-8.

28. S Naidu P, S Durga, R Baby Nalanda, Bolla N, Atla SR. A validated stability indicating RP-HPLC method for the simultaneous determination of atorvastatin calcium and ezetimibe hydrochloride in bulk and tablet dosage form. Int J Pharm Pharm Sci 2016;8:370-7.

29. Akabari AH, Suhagia BN, Saralai MG, Sutariya VA. Development and validation of stability indicating RP-HPLC method for estimation of fluvastatin sodium in bulk and capsule dosage form. Eurasian J Anal Chem 2017;12:87-105.

30. Gomes FP, Garcia PL, Alves JMP, Singh AK, Kedor-Hackmann ERM, Santoro MIRM. Development and validation of stabilityindicating HPLC methods for quantitative determination of pravastatin, fluvastatin, atorvastatin, and rosuvastatin in pharmaceuticals. Anal Lett 2009;42:1784-804.

31. Aglawe KV, Kharat UP, Dongaonkar CC, Chavan VA. Development and validation of stability indicating UV spectrophotometric method for the determination of pitavastatin calcium. World J Pharm Pharm Sci 2016;5:1773-87.

32. Akabari AH, Shah DR, Shah SA, Suhagia BN. Kinetic determinations of pitavastatin calcium by a stability indicating HPTLC method. J Liq Chromatogr Relat Technol 2015;38:521-31.

33. Damle MC, Polawar AR. Stability-indicating HPTLC method for the estimation of pitavastatin calcium in the presence of acid-induced degradation product. Int J ChemTech Res 2014;6:2824-33.

34. HJ Panchal BNS. Stability-indicating liquid chromatographic method for analysis of pitavastatin calcium in tablet dosage forms. Acta Chromatogr 2011;23:81-94.

35. Sujatha K, Seshagiri Rao JVLN. A new validated stabilityindicating RP-HPLC method for the estimation of pitavastatin in tablet dosage forms. Int J Pharm Anal Res 2014;3:67-73.

36. Onal A, Sagirli 0. Development of a selective LC method for the determination of pravastatin sodium. Chromatographia 2006;64:157-62.

37. Athota RV, Jagarlapudi SK, Singampalli MR. Stability indicating HPLC method for the simultaneous quantification of aspirin and pravastatin in bulk and tablets: method development and validation. J Appl Pharm Sci 2017;7:48-56.

38. A Ahmad, BP Panda, Mujeeb M. A validated stability-indicating method for simultaneous analysis of mevastatin and pravastatin in fermentation broth during bioconversion by Actinomadura macra. Acta Chromatogr 2011;23:121-31.

39. Reddy GR, Reddy PR, Jyothi PS. Development of a stabilityindicating stereoselective method for quantification of the enantiomer in the drug substance and pharmaceutical dosage form of rosuvastatin calcium by an enhanced approach. Sci Pharm 2015;83:279-96.

40. Venkat G, Reddy R, Reddy BV, Haque SW, Gautam HD, Kumar P. Development and validation of a stability-indicating UPLC method for rosuvastatin and its related impurities in pharmaceutical dosage forms. Quim Nov 2011;34:250-5.

41. Mostafa NM, Badawey AM, Lamie NT, El-Aleem EBA. Selective chromatographic methods for the determination of rosuvastatin calcium in the presence of its acid degradation. J Liq Chromatogr Relat Technol 2014;37:2182-96.

42. Badawy AMRM, Mostafa NM, El ABD, Abd AB, Aleem EL, Lamie NT. Stability-indicating PLS and PCR chemometric methods for the determination of rosuvastatin in presence of its two oxidative degradation products. Int J Pharm Pharm Sci 2011;3:232-7.

43. Trivedi HK, Patel MC. Development and validation of a stability-indicating RP-UPLC method for determination of rosuvastatin and related substances in the pharmaceutical dosage form. Sci Pharm 2012;80:393-406. 
44. Shah RP, Sahu A, Singh S. LC-MS/TOF, LC-MS, on-line H/D exchange and LC-NMR studies on rosuvastatin degradation and in silico determination of toxicity of its degradation products: a comprehensive approach during drug development. Anal Bioanal Chem 2013:405:3215-31

45. Ashfaq M, Akhtar T, Mustafa G, Danish M, Naeem S, Nazar MF. Simultaneous estimation of rosuvastatin and amlodipine in pharmaceutical formulations using stability indicating HPLC method. Brazilian J Pharm Sci 2014;50:629-36.

46. Mukthinuthalapati MA, Bukkapatnam V, Pavan S, Bandaru K. Stability indicating liquid chromatographic method for the simultaneous determination of rosuvastatin and ezetimibe in pharmaceutical formulations. Adv Pharm Bull 2014;4:405-11.

47. Belal F, Ibrahim F, Khedr A, Elawady T. Stability indicating TLC method for the determination of rosuvastatin and identification of some degradation products using electrospray ionization mass spectrometry. J Liq Chromatogr Relat Technol 2014;37:1114-32

48. Kapuganti ANK, Gandhi BM, Raju VB, Sumanth KS, Kagitapurapu VK, Srinivas K, et al. Development and validation of stability indicating RP-HPLC method for simultaneous estimation of ramipril, aspirin, and simvastatin in bulk and pharmaceutical dosage form. Asian J Biomed Pharm Sci 2016;6:14-20.

49. El Karbane M, Azougagh M, Al Kamarany MA, Bouchafra H, Cherrah Y, Bouklouze A. Development and validation of a reversed-phase HPLC method for simultaneous analysis of butylhydroxyanisol, simvastatin, and its impurities in tablet dosage forms. Ann Pharm Fr 2014:72:244-55.

50. Kumar P, Chakraborthy GS. Stability indicating RP-HPLC method development for determination of simvastatin in dosage forms. World J Pharm Sci 2014;3:1189-205

51. Rao KLN, Krishnaiah C, Reddy KP. Stability-indicating liquid chromatographic method for the simultaneous determination of ascorbic acid, citric acid, butylated hydroxyanisole, simvastatin, and related compounds in the pharmaceutical solid dosage form. Int J Anal Pharm Biomed Sci 2014;3:1-10.

52. Devu S, Gupta A, Srinivas KS, Gupta RS, Semwal VP. Chromatography development and validation of stability indicating RP-UPLC method for simultaneous determination in fixed dose combination of ezetimibe and simvastatin. J Chromat Separation Techniq 2012;3:1-7.

53. Gomes FP, Garcia PL, Alves JMP, Singh AK, Kedor-Hackmann ERM, Santoro MIRM. UV-derivative spectrophotometric and stability-indicating high-performance liquid chromatographic methods for determination of simvastatin in tablets. Latt Am J Pharm 2009;28:261-9.

54. Silva TD, Oliveira MA, Oliveira RB De, Vianna-Soares CD. Development and validation of a simple and fast HPLC method for determination of lovastatin, pravastatin, and simvastatin. J Chromatogr Sci 2012;50:831-8.

55. Ghodke SS. Stability indicating RP-HPLC method for simvastatin and sitaglipin phosphate with degradation studies in marketed pharmaceutical hypo-cholesterol and antidiabetic tablets. Int J Pharm Chem Biol Sci 2018;8:99-109.

56. Chavhan V, Ghante M. Stability indicating UV spectrophotometric method development and validation of simvastatin in bulk and tablet dosage form. J Appl Pharm 2014;6:235-46

57. Sawant $\mathrm{S}$, Ghante M. A validated stability indicating RP-HPLC method for simvastatin, identification and characterization of forced degradation products of simvastatin using LC-ESIMS/MS. Adv Anal Chem 2015;5:8-16.

58. Malenovic A, Jancic-Stojanovic B, Ivanovic D, Medenica M. Forced degradation studies of simvastatin using microemulsion liquid chromatography. J Liq Chromatogr Relat Technol 2010;33:536-47.

59. Nalaiya J, Sagineedu SRAO, Rajasingam R, Kassim Z, Pichika MRAO. A stability-indicating RP-HPLC method for simultaneous determination of simvastatin and niacin in a combined dosage form. Int J Pharm Pharm Sci 2015;7:262-8 